\title{
PERBEDAAN STATUS ANEMIA GIZI BESI REMAJA PUTRI YANG BERSEKOLAH DI SMA PROGRAM DAN NON-PROGRAM SUPLEMENTASI TABLET TAMBAH DARAH
}

\author{
The Difference in the Status of Anemia in Young Women High School Students Program and Non-Program \\ Iron Supplementation Tablet
}

\author{
*Antun Rahmadi \\ Department of Nutrition, Poltekkes Tanjungkarang, Jl. Soekarno-Hatta No. 1-6, Lampung, Indonesia \\ *e-mail: antunrahmadi@poltekkes-tjk.ac.id
}

\begin{abstract}
ABSTRAK
Hasil Riskesdas tahun 2013 menunjukkan bahwa kejadian anemia pada remaja putri masih tinggi yaitu sebesar 22,7\%. Salah satu upaya yang dilakukan pemerintah Indonesia dalam menanggulangi masalah anemia pada remaja putri adalah dengan mendidtribusikan tablet tambah darah (TTD) kepada siswi sekolah. Program suplementasi TTD bagi remaja putri saat ini belum mencakup seluruh institusi pendidikan setingkat SMP atau SMA. Hal itu menimbulkan pertanyaan apakah ada perbedaan status anemia antara sekolah yang sudah melaksanakan program suplementasi TTD dengan sekolah yang belum melaksanakannya. Tujuan umum penelitian ini adalah untuk mengetahui status anemia gizi besi siswi di SMA.Tujuan khusus penelitian adalah untuk 1) mengetahui status anemia gizi besi siswi di SMA program suplementasi TTD, 2) mengetahui status anemia gizi besi siswi di SMA non-program suplementasi TTD dan 3) mengetahui perbedaan status anemia gizi besi siswi di SMA program suplementasi TTD dan non TTD. Sampel penelitian ini diambil secara acak dari dua sekolah di Bandar Lampung yaitu SMKN 1 sebanyak 75 orang danSMA Al-Azhar sebanyak 72 orang. Pengolahan data dilakukan dengan bantuan komputer dan uji beda dilakukan dengan uji statistik kai kuadrat.Hasil penelitian menunjukkan bahwa kejadian anemia di SMKN 1 sebesar 24,0\% sedangkan di SMA Al-Azhar sebesar 43,1\%. Ada perbedaan yang bermakna antara kejadian anemia di SMKN 1 SMA Al-Azhar dengan nilai $\mathrm{p}=0,023$. Dinas Kesehatan diharapkan dapat memperluas cakupan program pemberian TTD ke sekolah yang belum tercakup dalam program suplementasi TTD. Pihak sekolah dapat berperanserta dalam menyediakan TTD secara swadaya.
\end{abstract}

Kata Kunci: Anemia, Remaja putri, Program pemberian TTD

\begin{abstract}
The results of Riskesdas in 2013 showed that the incidence of anemia in young women was still high at $22.7 \%$. One of the efforts made by the Indonesian government in overcoming the problem of anemia in young women is by distributing iron supplementation tablets (TTD) to school girls. The TTD supplementation program for young women currently does not cover all educational institutions at the junior or senior high school level. This raises the question whether there are differences in anemia status between schools that have implemented TTD supplementation programs and schools that have not implemented them. The general purpose of this study was to determine the anemia status of iron nutrition in high school students. The specific objectives of the study were to 1) determine the status of anemia in high school studentswith TTD supplementation program, 2) determine the status of anemia in high school students with non-TTD supplementation program and 3) find out the difference in status of anemiabetween both high school students. The sample of this study was taken randomly from two schools in Bandar Lampung, namely SMK 1 as many as 75 people and Al-Azhar High School as many as 72 people. Data processing is carried out with the computer and a different test is carried out by testing the kai quadratic statistics. The results showed that the incidence of anemia at SMK 1 was 24.0\% while at Al-Azhar High School was 43.1\%. There was a significant difference between the incidence of anemia at SMK 1 Al-Azhar High School with a value of $p=0.023$. The Health Service is expected to expand the coverage of the TTD program to schools that have not been covered by the TTD supplementation program. The school can participate in providing self-help TTD.
\end{abstract}

Keywords: Anemia, adolescent, iron supplementation programe

\section{PENDAHULUAN}

Di Indonesia, anemia masih menjadi masalah kesehatan masyarakat khususnya pada Wanita Usia
Subur (WUS), ibu hamil dan remaja putri. Data terbaru tentang prevalensi anemia di Indonesia adalah hasil Riset Kesehatan Dasar yang dilakukan pada tahun 2013 (Kemenkes.RI, 2013). Menurut sumber tersebut 
kejadian anemia pada remaja putri masih tinggi, yaitu sebesar $22,7 \%$.

Remaja putri merupakankelompok yang rawan terhadapanemia karena masa remajamerupakan masa pertumbuhan yangmembutuhkan zat gizi lebih tinggitermasuk zat besi. Selain itu,kebutuhan zat besi remaja putri jugamengalami peningkatan akibat kehilangan darahmelalui siklus haid setiap bulan. Sedangkan dari sisi asupan zat besi padaumumnya masyarakat Indonesia(termasuk remaja putri) lebih banyakmengkonsumsi makanan yang berasal dari sumber nabatiyang kandungan zat besinya lebihsedikit, dibandingkan denganmakanan yang berasal dari hewani, sehingga asupanzat besi sebagian besar remaja putritidak mencukupi kebutuhan harian sesuai dengan yang dianjurkan (Arisman, 2007).

Briawan (2014) menyebutkan bahwa faktor yang menyebabkan tingginya angka kejadian anemia pada remaja diantaranya rendahnya asupan zat besi dan zat gizi lainnya misalnya $\mathrm{A}, \mathrm{C}$, folat, riboflavin dan $\mathrm{B} 12$, kesalahan dalam konsumsi zat besi misalnya konsumsi zat besi bersamaan dengan zat lain yang dapat mengganggu penyerapan zat besi tersebut. Konsumsi pangan yang rendah kandungan zat besi dapat menyebabkan ketidakseimbangan besi di dalam tubuh. Selain itu, tingginya konsumsi pangan yang dapat menghambat penyerapan besi dan rendahnya konsumsi pangan yang dapat membantu penyerapan besi di dalam tubuh juga dapat menyebabkan ketidakseimbangan besi di dalam tubuh. Jika hal tersebut berlangsung dalam jangka waktu yang lama, maka dapat menyebabkan defisiensi besi (Almatsier 2009).

Anemia pada remaja putri dapat berdampak panjang untuk dirinya dan juga untuk anak yang kelak akan dilahirkan. Anemia pada masa remaja dapat menimbulkan gejala lesu, lemah, letih, lelah, konsentrasi belajar menurun, serta pertumbuhan fisik dan perkembangan otak terhambat. Selain itu anemia dapat meningkatkan risiko menderita penyakit infeksi karena daya tahan tubuh menjadi menurun yang berdampak pada tubuh mudah terkena infeksi. Pada remaja yang masih sekolah akan menurunkan kemampuan akademis, karena tidak adanya gairah dan konsentrasi belajar. Bagi remaja yang sudah bekerja, anemia akan menurunkan produktivitas kerja (Adan, 2011). Kondisi anemia yang berlanjut sampai usia dewasa hingga wanita tersebut hamil, dapat menimbulkan risiko terhadap bayinya. Wanitahamil yang menderita anemia dapat meningkatkan risiko kelahiran bayi prematur dan bayi dengan berat badan rendah. Selain itu, prevalensi anemia gizi yang tinggi ikalangan remaja berkontribusi besar terhadap angka kematian ibu, bayi lahir prematur dan bayi dengan berat lahir rendah. Hal tersebut tampaknya merupakan pangkal permasalahan kesehatan maternal dan neonatal yang buruk dan sulit dikendalikan. (Kemenkes RI, 2016)

Mengingat dampak yang terjadi sebagai akibat anemia sangat merugikan untuk masa mendatang, maka usaha pencegahan perlu dilakukan. Mencegah anemia pada remaja putri menjadi sangat penting, karena nantinya wanita yang menderita anemia dan hamil akan menghadapi banyak resiko, yaitu abortus, melahirkan bayi dengan berat lahir rendah, mengalami penyulit lahirnya bayi karena rahim tidak mampu berkontraksi dengan baik ataupun karena tidak mampu meneran, perdarahan setelah persalinan yang sering berakibat kematian.

Di Indonesia sebagian besar anemia disebabkan karena kekurangan zat besi (Fe) hingga disebut Anemia Gizi Besi (AGB). Oleh karena itu upaya yang dilakukan untuk mencegah dan menanggulangi AGB adalah dengan mencukupi kebutuhan tubuh akan zat besi. Almatzier (2009) menjelaskan cara mencegah anemia adalah dengan meningkatkan konsumsi makanan yang mengandung zat besi baik dari makanan hewani seperti daging, ikan, ayam, telur, hati dan bahan makanan nabati seperti sayur-sayuran hijau, daun bayam, daun singkong, daun papaya, kacangkacangan. Selain itu perlu menghindari atau mengurangi makanan atau minuman yang dapat mengganggu penyerapan zat besi seperti susu, kopi, dan teh dan memperbanyak konsumsi buah-buahan yang mengandung vitamin $\mathrm{C}$ seperti jeruk, papaya, pisang dan jambu serta minum suplemen tablet tambah darah (TTD) seminggu sekali atau setiap hari selama haid.

Sejak tahun 1996 Kementerian Kesehatan telah melakukan pengembangan pencegahan dan 
penanggulangan anemia pada remaja putri dan calon pengantin dilakukan secara mandiri di beberapa daerah untuk meningkatkan status kesehatan dan gizi prahamil sebagai persiapan untuk seorang ibu, agar ibu hamil tidak anemia dan melahirkan bayi yang sehat. Rekomendasi WHO pada World Health Assembly (WHA) ke-65 yang menyepakati rencana aksi dan target global untuk gizi ibu, bayi, dan anak, dengan komitmen mengurangi separuh $(50 \%)$ prevalensi anemia Program Pencegahan \& Penanggulangan Anemia pada remaja putri dan WUS pada tahun 2025. Menindaklanjuti rekomendasi tersebut maka pemerintah Indonesia melakukan intensifikasi pencegahan dan penanggulangan anemia pada remaja putri dan WUS dengan memprioritaskan pemberian TTD melalui institusi sekolah.

Rencana Strategis Kementerian Kesehatan RI tahun 2015-2019 menargetkan cakupan pemberian TTD pada rematri secara bertahap dari 10\% (2015) hingga mencapai 30\% (2019). Diharapkan sektor terkait ditingkat pusat dan daerah mengadakan TTD secara mandiri sehingga intervensi efektif dengan cakupan dapat dicapai hingga 90\% (The Lancet Series Maternal and Child Nutrition, 2013).

\section{METODE PENELITIAN}

Penelitian ini termasuk penelitian observasional analitik. Rancangan yang digunakan dalam penelitian adalah cross sectional, dimana pengukuran variabel dilakukan pada satu waktu. Dipilihnya rancangan penelitian cross sectional karena selain cukup sederhana, murah, dan cepat, yang paling penting juga adalah bahwa bisa menjawab tujuan penelitian yang ditetapkan.

Populasi dalam penelitian ini adalah seluruh siswi SMK Negeri 1 yang mendapatkan TTD sebanyak 522 orang dan SMA Al-Azhar sebanyak 406 orang. Besar sampel dihitung menggunakan rumus Lameshow sehingga diperoleh besar sampel di SMKN 1 Bandar Lampung sebesar 75 orang dan di SMA Al-Azhar sebesar 72 orang.

Data yang dikumpulkan dalam penelitian ini adalah data primer tentang status anemia, variabel umur, berat badan, tinggi badan, lama mentruasi, konsumsi teh, dan asupan zat gizi. Data status anemia dikumpulkan dengan cara pengukuran kadar $\mathrm{Hb}$ sedangkan variabel lainnya dikumpulkan dengan cara wawancara menggunakan instrumen penelitian berupa kuesioner pengumpulan data. Data primer dikumpulkan oleh peneliti dibantu dua orang mahasiswa Jurusan Gizi dan Jurusan Analis Kesehatan. Variabel hasil olah data dikategorikan sesuai definisi operasional dan siap untuk dianalisis. Analisis data dilakukan dengan bantuan komputer dan uji yang dipilih untuk menentukan hubungan variabel adalah uji statistik kai kuadrat.

\section{HASIL DAN PEMBAHASAN}

Status anemia gizi siswi SMKN 1 Bandar lampung secara rinci dapat dilihat pada tabel 1 berikut ini.

TABEL 1. Status anemia siswi SMKN 1 Bandar Lampung Tahun 2015

\begin{tabular}{l|l|l}
\hline \multirow{2}{*}{ Status Anemia } & Anemia & \\
\cline { 2 - 3 } & $\mathrm{n}$ & $\%$ \\
\hline Tidak anemia & 57 & 76,0 \\
Anemia ringan & 11 & 14,7 \\
Anemia sedang & 6 & 8,0 \\
Anemia berat & 1 & 1,3 \\
Jumlah & 75 & 100,0 \\
\hline
\end{tabular}

Hasil penilaian status anemia siswi SMA AlAzhar Bandar Lampung juga dapat dilihat pada tabel 2.

TABEL 2. Status anemia siswi SMA Al-Azhar Bandar Lampung Tahun 2015

\begin{tabular}{l|l|l}
\hline \multirow{2}{*}{ Status Anemia } & Anemia & \\
\cline { 2 - 3 } & $\mathrm{n}$ & $\%$ \\
\hline Tidak anemia & 41 & 56,9 \\
Anemia ringan & 10 & 13,9 \\
Anemia sedang & 18 & 25,0 \\
Anemia berat & 3 & 4,2 \\
Jumlah & 72 & 100,0 \\
\hline
\end{tabular}

Hasil penelitian menunjukkan bahwa prevalensi anemia siswi di kedua sekolah cukup tinggi yaitu sebesar 24\% di SMKN 1 Bandar Lampung dan 43,1\% di SMA Al-Azhar Bandar Lampung. Prevalensi anemia di kedua sekolah tersebut selengkapnya dapat dilihat pada tabel 3 . 
Perbedaan status anemia antara SMKN 1 Bandar

Lampung dengan SMA Al-Azhar yang diuji dengan uji

statistik khai kuadrat secara rinci dapat dilihat pada

tabel 4.

TABEL 3. Perbedaan Prevalensi anemia siswi SMKN 1 dan SMA Al-Azhar Bandar Lampung Tahun 2015

\begin{tabular}{|c|c|c|c|c|c|c|c|c|}
\hline \multirow{2}{*}{ Sekolah } & \multicolumn{2}{|c|}{ Anemia } & \multicolumn{2}{|c|}{ Tidak Anemia } & \multicolumn{2}{|c|}{ Jumlah } & \multirow[t]{2}{*}{ OR $95 \% \mathrm{CI}$} & \multirow[t]{2}{*}{ Nilai $p$} \\
\hline & $\mathrm{n}$ & $\%$ & $\mathrm{n}$ & $\%$ & $\mathrm{n}$ & $\%$ & & \\
\hline SMKN 1 Bandar Lampung & 18 & 24,0 & 57 & 76,0 & 75 & 100 & \multirow{3}{*}{2,4} & \multirow{3}{*}{0,023} \\
\hline SMA Al-Azhar Bandar Lampung & 31 & 43,1 & 41 & 56,9 & 72 & 100 & & \\
\hline Jumlah & 49 & 33,3 & 98 & 66,7 & 147 & 100 & & \\
\hline
\end{tabular}

SMKN 1 Bandar Lampung adalah salah satu SMA di Bandar Lampung yang melaksanakan program suplementasi TTD bagi siswinya. Pemberian TTD bagi semua siswi yang dilaksanakan setiap minggu sekali dengan dosis 1 tablet terbukti dapat meningkatkan status anemia pada siswinya. Tabel 1 memperlihatkan bahwa siswi SMKN 1 Bandar Lampung yang tidak anemia sebesar $76 \%$.

Kondisi yang berbeda terjadi di SMA Al-Azhar, sebagai sekolah yang belum melaksanakan program suplementasi TTD ternyata status anemia siswinya kurang begitu baik. Tabel 2 menunjukkan bahwa hanya $56,9 \%$ yang tidak anemia dan selebihnya mengalami anemia mulai dari tingkat ringan, tingkat sedang, bahkan ada yang tingkat berat.

Jika dilihat prevalensi anemia pada siswi dikedua sekolah menunjukkan angka yang cukup tinggi. Menurut WHO dan FAO (2006) prevalensi anemia siswi di SMKN1 Bandar Lampung termasuk dalam kategori sedang dan prevalensi anemia siswi di SMA Al-Azhar berada pada kategori berat. Analisis statistik yang disajikan pada tabel 3 menunjukkan bahwa ada perbedaan yang bermakna antara prevalensi anemia siswi SMKN 1 Bandar Lampung dengan SMA Al-Azhar Bandar lampung dengan nilai p 0,023. Hasil tersebut juga menunjukkan bahwa siswi yang bersekolah di SMA Al-Azhar 2,4 kali lebih berisiko mengalami anemia jika dibandingkan dengan siswi yang bersekolah di SMKN 1 Bandar Lampung.

Meningkatkan asupan makanan sumber zat besi merupakan pilihan pertama untuk mencegah terjadinya anemia.Namun demikian pada keadaan dimana zat besi dari makanan tidak mencukupi kebutuhan terhadap zat besi, perlu didapat dari suplementasi zat besi. Pemberian suplementasi zat besi secara rutin selama jangka waktu tertentu bertujuan untuk meningkatkan kadar hemoglobin secara cepat, dan perlu dilanjutkan untuk meningkatkan simpanan zat besi di dalam tubuh.

Suplementasi TTD pada remaja putri dan WUS merupakan salah satu upaya pemerintah Indonesia untuk memenuhi asupan zat besi.Pemberian TTD dengan dosis yang tepat dapat mencegah anemia dan meningkatkan cadangan zat besi di dalam tubuh.Penelitian ini sesuai dengan penelitian di Kupang (NTT) pada remaja putri tahun 2002, menunjukkan bahwa suplementasi TTD secara mingguan selama 16 minggu mampu meningkatkan kadar hemoglobin dan serum feritin lebih besar dibandingkan suplementasi TTD 4 hari berturut-turut saat menstruasi selama 4 siklus menstruasi. Penelitian yang dilakukan pada siswi SMA di Tasikmalaya menunjukkan bahwa pemberian TTD 1 kali seminggu dibandingkan dengan pemberian TTD 1 kali seminggu ditambah setiap hari selama 10 hari saat menstruasi, dapat meningkatkan kadar $\mathrm{Hb}$ tetapi tidak terdapat perbedaan bermakna antara kedua kelompok tersebut. Di beberapa negara lain seperti: India, Bangladesh, dan Vietnam, pemberian TTD dilakukan 1 kali seminggu dan hal ini berhasil menurunkan prevalensi anemia di negara tersebut. Berdasarkan penelitian di Indonesia dan di beberapa negara lain tersebut, maka pemerintah menetapkan kebijakan program pemberian TTD pada remaja putri dan WUS dilakukan setiap 1 kali seminggu dan sesuai dengan Permenkes yang berlaku. Dalam hal ini, seluruh remaja putri dan WUS diharuskan minum TTD untuk mencegah anemia dan meningkatkan cadangan zat besi dalam tubuh tanpa dilakukan skrining awal pada kelompok sasaran.

Untuk meningkatkan penyerapan zat besi 
sebaiknya TTD dikonsumsi bersama dengan buahbuahan sumber vitamin $\mathrm{C}$ (jeruk, pepaya, mangga, jambu biji dan lain-lain). Sumber protein hewani, seperti hati, ikan, unggas dan daging. Selain itu perlu menghindari mengonsumsi TTD bersamaan dengan teh dan kopi karena mengandung senyawa fitat dan tanin yang dapat mengikat zat besi menjadi senyawa yang kompleks sehingga tidak dapat diserap.

Suplementasi zat besi berkaitan secara signifikan dengan penurunan risiko anemia (WHO, 2016). Rekomendasi WHO pada World Health Assembly (WHA) ke-65 yangmenyepakati rencana aksi dan target global untuk gizi ibu, bayi, dananak, dengan komitmen mengurangi separuh (50\%) prevalensi anemiapada WUS pada tahun 2025. Menindaklanjuti rekomendasi tersebutmaka pemerintah Indonesia melakukan intensifikasi pencegahan danpenanggulangan anemia pada remaja putri dan WUS denganmemprioritaskan pemberian TTD melalui institusi sekolah. Rencana Strategis Kementerian Kesehatan RI tahun 20152019menargetkan cakupan pemberian TTD pada remaja putri secara bertahap dari10\% (2015) hingga mencapai 30\% (2019). Diharapkan sektor terkait ditingkat pusat dan daerah mengadakan TTD secara mandiri sehingga intervensi efektif dengan cakupan dapat dicapai hingga $90 \%$.

\section{KESIMPULAN}

Siswi SMKN1 Bandar Lampung yang tidak anemia sebesar 76,0\% dan yang anemia sebesar 24,0\% sedangkan siswi SMA Al-Azhar Bandar Lampung yang tidak anemia sebesar $56,9 \%$ dan yang anemia sebesar 43,1\%. Ada perbedaan prevalensi anemia antara siswi SMKN1 Bandar Lampung dengan SMA Al-Azhar Bandar Lampung. Bagi Dinas Kesehatan agar dapat memperluas cakupan program suplementasi TTD ke sekolah yang belum melaksanakan program tersebut dengan dukungan teknis dan logistik TTD. Bagi SMA Al-Azhar dapat ikut berpartisipasi dalam pelaksanaan program suplementasi dengan menyediakan TTD secara swadaya.

\section{DAFTAR PUSTAKA}

Adan K. 2011.Pedoman penanggulangan anemia gizi untuk remaja putri dan wanita usia subur. [online]. Tersedia http://www.kalbemed.com/ [18 Januari 2018]

Almatzier, Sunita. 2009. Prinsip Dasar Ilmu Gizi. Jakarta: Pustaka Utama.

Arisman, 2007.Gizi Dalam Daur Hidup. Cetakan Ketiga. Jakarta: EGC.

Briawan, D. 2014. Anemia. Masalah Gizi Pada Remaja Wanita. Jakarta: EGC

Kemenkes.RI, 2013.Riskesdas dalam angka Indonesia tahun 2013. Jakarta: Badan Penelitian dan Pengembangan Kesehatan Kementerian Kesehatan RI.

Kemenkes.RI, 2016.Pedoman Pencegahan dan Penanggulangan Anemia pada Remaja Putri dan WUS. Jakarta: Kemenkes RI, Dirjen.Kesmas.

WHO \& FAO, 2006. Guidelines on food fortification with micronutrients. 